Joanna Grzela

Uniwersytet Jana Kochanowskiego w Kielcach

DOI: $10.19195 / 2450-274 X .2 .10$

\title{
Meandry norweskiej europejskości
}

Abstrakt: Norwegia jest częścią Europy, nie tylko geograficznie, ale również pod względem historycznym, finansowym i kulturowym. Unia Europejska jest najważniejszym partnerem handlowym tego państwa, a polityka UE ma wpływ na wiele sektorów życia norweskiego. Pomimo to Norwegowie dwukrotnie w referendum odrzucili członkostwo w Unii Europejskiej. Jest wiele powodów tej decyzji. Wśród nich najczęściej podkreślane - gospodarczy. Norwegowie nie chcą dzielić się zyskiem z połowu ryb, a tym bardziej surowcami naturalnymi. Ich gospodarka jest zdrowa i dobrze prosperuje, nie będąc częścią Unii Europejskiej. Norweska nieobecność w UE jest więc niczym innym, jak instynktem samozachowawczym, a eurosceptycyzm Norwegów jest oparty na przywiązaniu do autonomii.

Słowa kluczowe: eurosceptycyzm, Norwegia, Unia Europejska

\section{Meanders of Norwegian Europeanism}

Abstract: Norway is a part of Europe, not only geographically, but historically, financially and culturally. The European Union is the main trading partner of that country, and EU policies have an impact on many sectors of Norwegian life. Despite this, the Norwegians twice in a referendum rejected membership in the European Union. There are many reasons for this decision. Among them, the most stressed - economic reasons. Norwegians do not want to share profits from fishing, and, what is more, the extraction of natural resources. Norwegian economy is healthy and prospers well without being part of the European Union. Norwegian absence in the EU is therefore nothing other than self-preservation and Norwegians Euroscepticism is based on a commitment to autonomy.

Keywords: Euroscepticism, Norway, the European Union

\section{Wstęp}

Norwegia to kraj silny w regionie nordyckim i pomimo pozostawania poza strukturą Unii Europejskiej (UE) również na jej obszarze. Norwegowie jako je- 
dyni dwukrotnie zagłosowali przeciwko członkostwu w UE podczas referendów w latach siedemdziesiątych i dziewięćdziesiątych XX w. Sceptycyzm dotyczący integracji wynika m.in. z dobrej ekonomicznej sytuacji Norwegii. Mimo negatywnej opinii mieszkańców w sprawie przystąpienia do UE kraj ten ściśle współpracuje z Unią w większości spraw. W 2001 r. Norwegia przystąpiła do współpracy w ramach Schengen. W dziedzinie polityki bezpieczeństwa i obrony kraj ten udostępnił swój personel cywilny i wojskowy do wykonywania prowadzonych przez UE operacji zarządzania sytuacjami kryzysowymi. Norwegia jest bardziej związana z grupą misji pokojowych Unii Europejskiej niż np. jej członek - Dania. Norwegia zasila unijny budżet coroczną składką, by zredukować społeczne i gospodarcze nierówności wewnątrz Europejskiego Obszaru Gospodarczego (EOG). Jej wkład roczny w niwelowanie społeczno-ekonomicznych dysproporcji w rozwoju Europy to około 350 milionów euro. W maju 2004 r. kraj ten ustanowił dwa nowe mechanizmy finansowe - EOG oraz odrębny mechanizm norweski wspierający nowe państwa członkowskie UE. Choć zdania dotyczące członkostwa w Unii Europejskiej są podzielone, wśród norweskich polityków panuje powszechna zgoda co do tego, że Norwegia powinna być aktywnym i konstruktywnym partnerem we współpracy z Europą. Dziś, pozostając poza UE, przyczynia się do społecznego i gospodarczego rozwoju oraz stabilizacji na Starym Kontynencie. Dotychczasowe kontakty norwesko-unijne można opisać jako skomplikowany i czasem trudny do zrozumienia bieg wydarzeń.

Jeśli przyjąć kryterium problematyki, to prezentowany artykuł nie porusza tego tematu jako pierwszy. Jednak eurosceptycyzm jest ważnym i aktualnym tematem badań $\mathrm{z}$ wielu powodów, szczególnie w kontekście zdarzeń i procesów jakie mają miejsce w ostatnich latach na kontynencie europejskim. Po pierwsze dlatego, że kryzys strefy euro odsłonił napięcia i nieporozumienia pomiędzy krajami europejskimi (w związku z tym odżyły eurosceptyczne postawy i poglądy artykułowane w publicznym dyskursie). Po drugie prognozowane wyjście Wielkiej Brytanii z Unii Europejskiej sprowokowało dyskusję, w której brytyjscy konserwatyści poszukują analogii pomiędzy eurosceptycyzmem Norwegów i Brytyjczyków ${ }^{1}$. David Cameron postrzega bowiem kraje skandynawskie jako przykład dla Wielkiej Brytanii. To z jego inicjatywy powstało w 2011 r. „Northern Future Forum", które przerodziło się w cykliczne spotkania szefów rządów krajów nordyckich, bałtyckich i Wielkiej Brytanii. Niektórzy obserwatorzy oceniali ten pomysł jako brytyjski power play - próbę stworzenia „Ligi Północnej” z często eurosceptycznych, proatlantyckich państw, które podzielają chęć powstrzymania władzy Brukseli i rosnących wydatków $\mathrm{UE}^{2}$. Po trzecie premier Islandii, Sigmundur Gunnlaugsson, w marcu 2015 r. oznajmił, iż porzuca pomysł przystąpienia do Unii Europejskiej, gdyż interesy tego kraju będą lepiej reprezentowane poza Unią.

${ }^{1}$ Zob. The reluctant European. Special Report, „The Economist”, 17.10.2015.

${ }^{2}$ W. Bagehot, Nice up north. Why David Cameron is fascinated by Sweden and its neighbours, „The Economist”, 27.01.2011. 
Opisane wyżej przykłady stanowią świadectwo wagi poruszanej problematyki i narzucają pytanie o przyszłość Unii Europejskiej. Autorka w swoich rozważaniach koncentruje się na istocie i motywacji norweskiego eurosceptycyzmu - ponownie obecnego w publicznym dyskursie. W związku z tym stawia następujące pytania badawcze:

- co to jest norweski sceptycyzm?

- kiedy narodził się norweski eurosceptycyzm i czy nadal się rozwija?

— w jaki sposób można wyjaśnić źródła norweskiego sceptycyzm?

- co stanowi o specyfice eurosceptycyzmu w Norwegii?

- dlaczego Norwegia odrzuca akces do UE pomimo zaangażowania we wspieranie projektu integracji europejskiej?

W celu udzielenia odpowiedzi na powyższe pytania autorka zastosowała metody: analizy treści dokumentów i systemową. Analiza dokumentów, wypowiedzi polityków, dostępne dane statystyczne i ekonomiczne prowadzą do wniosku, iż przyczyn decyzji Norwegów jest wiele. Autorka artykułu przedstawia te najważniejsze, dokonując wyboru w sposób arbitralny.

Autorka zdaje sobie sprawę, iż ilustracja sprzeciwu Norwegów wobec Unii Europejskiej, jego źródeł, uwarunkowań oraz wpływu na kontakty z Unią, jest zadaniem o dużym znaczeniu. Dostrzega także fakt, iż złożoność tej problematyki nie pozwala ująć pełnego jej zakresu (ograniczenia objętościowe). Przykładem tego jest kwestia związana z kryzysem uchodźców. Jest to obszerne zagadnienie, wymagające odrębnych badań. Pomimo tego decyduje się na prezentację artykułu, uważając, iż może on stanowić przyczynek do dyskusji koncentrującej się wokół aktualnych powodów i specyfiki eurosceptycyzmu.

\section{Istota norweskiego eurosceptycyzmu}

Istnieje wiele definicji eurosceptyzmu. Słownik Oxfordzki podaje następującą definicję terminu „eurosceptyk”: „osoba, która sprzeciwia się zwiększeniu kompetencji Unii Europejskiej”3. Słowo „eurosceptycyzm” po raz pierwszy pojawiło się 11 listopada 1985 r. w brytyjskim „The Times”. Użyto go, by opisać sceptycyzm i sprzeciw wobec Unii Europejskiej i jej polityki (bardziej elastycznie niż „eurofobia” czy „antyeuropejskość”). „Eurosceptycyzm” zyskał na popularności po słowach premier Wielkiej Brytanii, Margaret Thatcher, wygłoszonych w Brugii w 1988 r. Thatcher wyraziła wówczas sprzeciw wobec propozycji sfederalizowania i centralizacji Wspólnot Europejskich ${ }^{4}$. W dyskursie publicznym termin ten zaczął

${ }^{3}$ Zob. http://www.oxforddictionaries.com/definition/english/Eurosceptic (dostęp: 3 sierpnia 2015).

${ }^{4}$ M. Spiering, What is British Euroscepticism, [w:] Euroscepticism: Party Politics, National Identity and European Integration, red. R. Harmsen, M. Spiering, „European Studies” 2004, nr 20, s. $128 \mathrm{n}$. 
się częściej pojawiać po przyjęciu Traktatu z Maastricht w 1992 r., który stworzył Unię Europejską i stał się fundamentem współpracy na kolejnych płaszczyznach (bezpieczeństwa, sprawiedliwości, spraw wewnętrznych i zagranicznych). Od tego czasu „eurosceptycyzm” jest używany na określenie negatywnej postawy wobec integracji europejskiej i Unii Europejskiej . Taggart i Szczerbiak rozróżniają „miękki” i „twardy” eurosceptycyzm. „Twardy” eurosceptycyzm odrzuca proces integracji europejskiej w ogóle, podczas gdy „miękki” obejmuje sprzeciw wobec niektórych aspektów procesu integracji (np. wspólnej waluty, polityki rolnej czy rybackiej) ${ }^{6}$.

Ponieważ ani partie polityczne, ani opinia publiczna nie istnieją w próżni, rozwój sytuacji w UE na początku lat dziewięćdziesiątych XX w. miał wpływ na społeczną ocenę dokonywanych przemian, będących efektem nowo tworzonych mechanizmów i postępującej integracji państw. Takiej recenzji dokonali m.in. Norwegowie. 28 listopada 1994 r. w Norwegii odbyło się referendum konsultacyjne w sprawie członkostwa w Unii Europejskiej. Głosów przeciw było 52,2\% wobec 47,8\% głosów oddanych na „tak”. Frekwencja wyniosła 88,6\%. Ten wynik skutecznie przekreślił plany Partii Pracy dotyczące członkostwa w UE i był ciosem dla premier Gro Harlem Brundtland, która uznała członkostwo Norwegii w UE za główny cel polityczny swojego rządu?

Kampania zwolenników członkostwa w UE skupiała się na potencjale Norwegii i potrzebie łączenia $\mathrm{z}$ sąsiednimi krajami w celu wzmocnienia gospodarki w dobie ekspansji i zmian. Rząd wśród korzyści z członkostwa wymieniał: wzmocnienie systemu opieki społecznej, wzrost zatrudnienia i wysoki wzrost gospodarczy, ochronę środowiska naturalnego Norwegii, nordycką solidarność w UE i bezpieczeństwo Norwegii ${ }^{8}$. C. Archer twierdzi, iż jedną z obaw zwolenników członkostwa Norwegii w UE było to, że po drugim referendum kraj ten będzie w Europie marginalizowany ${ }^{9}$.

${ }^{5}$ P. Taggart, A Touchstone of Dissent: Euroscepticism in Contemporary West European Party Systems, „European Journal of Political Research” 1998, nr 33 (3), s. 366.

${ }^{6}$ P. Taggart, A. Szczerbiak, Opposing Europe: Party Systems and Opposition to the Union, the Euro and Europeanisation, „OERN Working Paper” 2000, nr 1. Brighton: University of Sussex, Sussex European Institute; P. Taggart, A. Szczerbiak, Parties, Positions and Europe: Euroscepticism in the EU Candidate States of Central and Eastern Europe, „OERN Working Paper” 2001, nr 2. Brighton: University of Sussex, Sussex European Institute; P. Taggart, A. Szczerbiak, The Party Politics of Euroscepticism in EU Member and Candidate States, „OERN Working Paper” 2002, nr 6. Brighton: University of Sussex, Sussex European Institute; P. Taggart, A. Szczerbiak, Theorising Party-Based Euroscepticism: Problems of Definition, Measurement and Causality, „EPERN Working Paper" 2003, nr 12. Brighton: University of Sussex, Sussex European Institute.

7 Wcześniej, w podobnym referendum w 1972 r., Norwegowie zagłosowali przeciw wejściu do Wspólnoty Europejskiej po raz pierwszy w historii tego kraju. Odrzucili oni wówczas członkostwo stosunkiem głosów $54 \%$ do $46 \%$.

8 C. Archer, Norway and European Integration since 1994, „Queen's Papers on Europeanisation” 2001, nr 12, Dept of Politics \& Philosophy Manchester Metropolitan University.

9 Ibidem. 
Przeciwnicy twierdzili, że członkostwo w Unii mogłoby naruszyć niezależność kraju i jego kontrolę nad zasobami ropy naftowej i innych surowców naturalnych. Podkreślano różnice w prowadzonej polityce makroekonomicznej i strukturze gospodarczej między Norwegią a UE (gospodarka Norwegii jest oparta na zasobach naturalnych - ropie naftowej i rybach, podczas gdy Unia stawia na przemysł). Jako członek Norwegia stanęłaby w obliczu podjęcia decyzji dotyczącej wprowadzenia unii walutowej. Tymczasem, ze względu na szczególną strukturę gospodarczą (oparcie na eksporcie towarów), Norwegia jest krajem w Europie Zachodniej, w którym euro jest najmniej odpowiednie. Sukces norweskiej gospodarki ilustruje wartość utrzymania kontroli państwa nad walutą krajową i polityką makroekonomiczną. Ponadto istnieje przekonanie, że wartości demokratyczne są najbardziej cenione na poziomie krajowym i szczeblu lokalnym, a nie unijnym. Przeciwnicy integracji z UE podkreślali, że organizacja ta jest niedemokratyczna, neoliberalna i sprawia, że bogaci są bogatsi, a biedni biedniejsi ${ }^{10}$.

Norwegowie są sceptyczni i z niepokojem obserwują koncepcję liberalizmu gospodarczego budowaną w kolejnych traktatach UE. Ich wizja Europy zawiera inne postrzeganie wolności, nie tylko przez pryzmat czterech swobód rynku wewnętrznego. Są bowiem zwolennikami takiego rodzaju autonomii i wolności, które pozwalają władzom ograniczać wolny rynek, jeśli jest to konieczne w celu realizacji ważnych celów społecznych. Ponadnarodowe ustalenia są czasem konieczne, ale mają być wsparciem oddolnych decyzji i muszą być ograniczone do absolutnie niezbędnych. W debatach wskazywano na inny rodzaj problemów do rozwiązania przez Unię: rosnące bezrobocie, spadek roli państwa opiekuńczego, rozpadające się społeczności, zła sytuacja zdrowotna, narkomania oraz zwiększenie poziomu przemocy i przestępstw. Ponadto przedstawiciele norweskiego antyunijnego ruchu podkreślali, że UE powinna być ograniczona do wyzwań, które mogą być kontrolowane tylko na poziomie międzynarodowym: konflikty między krajami, problemy zanieczyszczenia środowiska naturalnego, wspólne minimalne standardy na rynku pracy i wspieranie równowagi społecznej pomiędzy regionami Europy ${ }^{11}$. Działaczka ruchu antyeuropejskiego, liderka norweskiej Partii Centrum i szefowa kampanii antyunijnej, Anna-Enger Lahnstein, powiedziała po referendum: „mówimy Tak dla Europy i Tak dla solidarności międzynarodowej, ale nie chcemy przystąpić do Unii" ${ }^{2}$.

Wyniki referendum symbolizują sceptycyzm społeczeństwa wobec przeniesienia ośrodka podejmowania ważnych decyzji poza Norwegię. Wielu wyborców

${ }^{10}$ M. Sundlisæter Skinner, Norwegian Euroscepticism: Values, Identity or Egotism? A Multi-level Mixed Methods Investigation, Bath 2011, s. 174.

${ }_{11}$ The rationale for opposing Norwegian membership in the European Union, http://www.neitileu.no/articles_in_foreign_languages/the_rationale_for_opposing_norwegian_membership_ in_the_european_union (dostęp: 28 sierpnia 2015).

${ }^{12}$ Cyt. za: http://news.bbc.co.uk/onthisday/hi/dates/stories/november/28/newsid_4208000/ 4208314.stm (dostęp: 3 sierpnia 2015). 
propozycję przystąpienia do Unii widziało jako paradoks w chwili, gdy sytuacja gospodarcza tego kraju była bardzo dobra ${ }^{13}$. Trudno zatem było przekonać opinię publiczną o korzyściach członkostwa w sensie ekonomicznym. Wielu Norwegów uważało, że przyszłość będzie bardziej bezpieczna i stabilna, jeśli wybiorą status quo. Głosowanie na rzecz członkostwa było postrzegane jako bardziej niepewne niż oddanie głosu przeciwko.

Od drugiego referendum minęło 21 lat. Unia Europejska zmieniła się w tym czasie. Mimo to nie wydaje się jednak prawdopodobne, by Norwegia ubiegała się o członkostwo zanim politycy z partii rządzących nie upewnią się, że wynik referendum będzie pozytywny. Trzecie "nie” mogłoby być definitywne. Koszty polityczne są bowiem postrzegane jako zbyt duże. „Nikt nie chce o tym mówić, ponieważ oznaczałoby to kwestionowanie społecznego werdyktu, ciągle jeszcze świeżego. Poruszanie tego tematu byłoby błędem taktycznym, ponieważ niewątpliwie spowodowałoby odejście wyborców do małych partii eurosceptycznych" mówił w 2002 r. przed wyborami parlamentarnymi prof. Tor Bjoerkelund z Uniwersytetu w Oslo, specjalista ds. europejskich. Mimo upływu lat ta opinia jest wciąż aktualna. W 2009 r. dr Espen D.H. Olsen z Centrum Studiów Europejskich „ARENA” Uniwersytetu w Oslo stwierdził: „Aby rząd mógł funkcjonować istnieje tak zwana »klauzula samobójcza«, która zakłada, że sprawa UE nie powinna być podnoszona w nadchodzącej kadencji. Gdyby było inaczej, koalicja się rozpadnie. Stąd wynika następujący wniosek: wewnętrzna polityka rządu jest znacznie bardziej ważna niż sprawy UE”. W jego opinii „w obu kampaniach stronie nawołującej do głosowania na »nie« udało się przedstawić UE jako projekt elit, który jako taki nie był zakorzeniony w obywatelach. Grupę zwolenników zaś stanowiła koalicja między konserwatystami, socjalistami i związkami zawodowymi, podczas gdy po przeciwnej stronie stała koalicja lewicowych socjalistów, rolników, rybaków i przedstawicieli ruchów kontrkulturowych"14.

W 1969 r. przyszłość norweskiej gospodarki zmieniła się wraz z odkryciem ropy naftowej na Morzu Północnym. To wówczas uczyniło ten kraj szóstym na świecie największym eksporterem ropy. W związku z tym często zakłada się, że norweski eurosceptycyzm ma swoje korzenie w obawie przed utratą kontroli nad rozległymi zasobami ropy naftowej i gazu ziemnego. Prof. Dag Harald Claes z Instytutu Nauk Politycznych na Uniwersytecie w Oslo twierdzi: „To, że nie jesteśmy członkiem Unii Europejskiej jest efektem dwóch referendów, jakie miały u nas miejsce. Wyjaśnić jednak trzeba, dlaczego większość obywateli głosowała przeciw. Częściowo jest to efektem przekonania, że cesja suwerenności w przypadku członkostwa byłaby bardzo rozległa i że doszłoby do utraty kontroli nad norweskimi zasobami naturalnymi, takimi jak ropa, ale przede wszystkim łowiskami

${ }^{13}$ W 1994 r. PKB Norwegii wzrósł o 5,1\%. Bezrobocie wynosiło 5,4\% (w wielu krajach UE było ono dwukrotnie wyższe), a inflacja wyniosła tylko $1,4 \%$. Kraj miał dodatni bilans handlowy.

${ }^{14}$ Cyt. za: J. Woliński, Referendum w Norwegii - komentarze ekspertów, http://www.psz. pl/168-archiwum/referendum-w-norwegii-komentarze-ekspertow (dostęp: 5 sierpnia 2015). 
i rybami"15. Istnieje jednak wiele innych czynników, które należy uwzględnić w tej ocenie zjawiska, razem stanowiących system naczyń połączonych. Są to:

- wyjątkowa historia - Skandynawia nie zawsze była spokojnym i harmonijnym zakątkiem Europy. Historia tego regionu sięga aż od epoki Wikingów w IX w. Tysiąc lat temu ludy skandynawskie zaczęły razem tworzyć wspólnotę. Wcześniej mieszkańcy Północy, którzy handlowali i łupili ziemie, byli znani jako Wikingowie oraz Waregowie. Obok rozboju zajmowali się oni także handlem, dzięki któremu istniała energiczna wymiana między głównymi miastami nadbałtyckimi. Doprowadziła ona do pierwszego w dziejach tego obszaru rozwoju gospodarczego, wymiany towarów, a tym samym zintensyfikowania kontaktów między krajami i ziemiami nadbałtyckimi a resztą cywilizowanego świata. Okres ten zakończył się wraz z nastaniem chrześcijaństwa, a dni plądrowania i grabieży dobiegły wówczas końca. Mimo to od czasu do czasu między królestwami skandynawskimi wybuchały wojny. Najstarsze dzieje regionu są owiane tajemnicą - wiadomo jednak, że pod koniec XI w. północne ziemie zostały podzielone pomiędzy trzy nowopowstałe królestwa Danii, Norwegii i Szwecji. Norwegia przez dłuższy czas w swojej historii była kontrolowana - szczególnie przez Szwedów i Duńczyków. Po ponad 500 latach konfliktów i partnerstwa stała się w pełni niezależnym krajem w $1905 \mathrm{r}$. Suwerenność po raz kolejny została zabrana przez hitlerowców w czasie II wojny światowej. Przebieg historii Norwegii odbił piętno na obronie niezależności. To był istotny element obu kampanii referendalnych, w których ważna była identyfikacja narodowa. Ustalenia z Maastricht i przemianowanie Wspólnoty na „Unię” wywołało u Norwegów negatywne skojarzenia z unią ze Szwecją i utratą suwerenności;

- religia - wiodącą religią w Norwegii jest protestantyzm. W myśl jej założeń tak jak dobra materialne powinny służyć innym, tak predyspozycje fizyczne i intelektualne powinny służyć całemu społeczeństwu. Z tego względu wyznawcom tej religii zabrania się spożywania alkoholu i narkotyków, a obowiązkiem każdego człowieka jest rozwijanie swoich zdolności i dbanie o duchowość. Purytańska moralność $\mathrm{z}$ jej akcentem na pracę, powołaniem i działalnością w sferze produkcji oraz z podkreśleniem prostoty życia, wstrzemięźliwość i skromność w sferze konsumpcji są cechami norweskiego społeczeństwa. Pomimo bogactwa pewna oszczędność i prostota są nadal uważane za właściwe w tym społeczeństwie. Dobra luksusowe są obciążone wysokimi podatkami, a alkohol może wciąż być zakupiony tylko w państwowych sklepach monopolowych po wygórowanych cenach; protestancki etos pracy, powszechne poczucie solidaryzmu społecznego oraz niezwykle wysoki poziom uczciwości obywatelskiej wyróżniają Norwegię na tle innych krajów Europy;

- silne poczucie tożsamości - proces zmian kulturowych powoduje wiele obaw mieszkańców kraju fiordów. Niektórzy Norwegowie obawiają się erozji

${ }^{15}$ Ibidem. 
ich odrębności kulturowej, a „odporność” na członkostwo w Unii Europejskiej jest wyrazem strachu i wskazania silnej i trwałej kulturowej samoświadomości; niektórzy narzekają na presję anglicyzmów w lokalnym dialekcie, inni martwią się standaryzacją i alienującymi wpływami kultury masowej w amerykańskim stylu;

— czynnik geograficzny — położenie Norwegii na peryferiach Europy implikuje obawy o słyszalność głosu norweskiego w unijnych instytucjach. Ponadto Norwegowie są zwolennikami decentralizacji i jak największych udogodnień w miejscu zamieszkania obywatela. Może o tym świadczyć niezwykle rozbudowana infrastruktura drogowa (liczne mosty, tunele łączące małe wysepki z lądem; prawie 50 portów lotniczych wybudowanych dla czteromilionowej populacji); język (który jest zdecentralizowany do tego stopnia, że każda dolina ma swój własny, półoficjalny dialekt, z którego przynajmniej część mieszkańców jest dumna); infrastruktura społeczna (placówki oświatowe, uniwersytety są dostępne w każdym powiecie, także szpitale regionalne, biblioteki, urzędy pocztowe i urzędy administracyjne różnego rodzaju są rozlokowane w bardzo wielu miejscowościach). W roku 1990 r. Biblioteka Narodowa została przeniesiona z Oslo do pięciotysięcznej, daleko położonej miejscowości Brønnøysund. Priorytetowe traktowanie obszarów peryferyjnych pozwala postawić tezę, iż norweska tożsamość jest rodzajem „wiejskiej lub małomiasteczkowej tożsamości”. W przypadku Norwegii powiedzenie - „małe jest piękne” jest niezmiennie aktualne;

- wysoki poziom kapitału społecznego, sukces państwa opiekuńczego i poczucie solidarności narodowej. Dość wyraźnie widać, iż północna część Europy wybrała inną drogę rozwoju, ale i inny model państwa - państwa dobrobytu, które ingeruje we wszystkie aspekty życia, w tym w gospodarkę, i m.in. dzięki temu większość z tych krajów ma lepsze wskaźniki społeczno-gospodarcze niż reszta Europy;

— działalność Norwegii w ramach polityki zagranicznej i międzynarodowa opinia o kraju jako rozjemcy konfliktów, wnoszącym wiele na rzecz pojednania; Norwegia, będąc promotorem dyplomacji publicznej i pokoju, może traktować członkostwo w UE jako potencjalną przeszkodę. Jest ona bowiem uznawana na arenie międzynarodowej za kluczowego mediatora i pośrednika w konfliktach politycznych, a szczególnie w misjach pokojowych w Somalii, Gwatemali, RPA, na Filipinach i Bliskim Wschodzie. To unikalne znaczenie i zaangażowanie Norwegii może w oczach społeczności międzynarodowej zostać utracone w przypadku akcesji do UE. Dzięki bardzo bliskim relacjom z Unią, ale i pozycji spoza UE, Norwegia może działać jako „budowniczy mostów” na arenie międzynarodowej, wspierać tworzenie koalicji i zabezpieczać szersze międzynarodowe wsparcie dla kluczowych inicjatyw. Wśród przeciwników akcesji przeważyła zatem także obawa, że kraj mógłby stracić swoją samodzielność w polityce międzynarodowej, jeśli stałby się częścią UE. Unia Europejska została po prostu oceniona jako zbyt mała dla takiego kraju jak Norwegia; 
— uzależnienie gospodarki Norwegii od sektorów eksportowych — przystąpienie tego kraju do UE oznaczałoby zgodę na kontrolę i władzę regulacyjną unijnych instytucji dla kluczowych branż i surowców (ryby, gaz ziemny, ropa naftowa, tarcica). Jest prawdopodobne, że kryzys finansowy z 2008 r. i obecne problemy strefy euro także przyczyniły się do ostrożności kraju w zakresie europeizacji i zaostrzenia norweskiego eurosceptycyzmu. Według danych Organizacji Współpracy Gospodarczej i Rozwoju (OECD) Norwegia to jeden z krajów, w których gospodarka rozwija się najszybciej. Mierząc i porównując produkt krajowy brutto (PKB) per capita, kraje nordyckie mają większe dochody niż UE. Wszystkie kraje skandynawskie mają wyższy wskaźnik PKB na osobę niż te w Unii. Norweski PKB per capita jest dwa razy wyższy niż w UE, co lokuje ten kraj wśród tych o najwyższym standardzie życia. Podczas gdy Portugalia, Hiszpania i Grecja wpadły w recesję, gospodarka Norwegii kwitła. Gdy wielu członków Unii wprowadziło rygorystyczne środki oszczędnościowe, prowokując niepokoje społeczne, Norwegia miała nadwyżkę budżetową. W 2008 r. jej gospodarka wzrosła o prawie $3 \%{ }^{16}$. Ponadto wielu Norwegów głosowało na „nie”, gdyż obawiano się, że norweska polityka dopłat i niezwykle silna w tym kraju pomoc rolnikom mogą zostać wyparte przez Wspólną Politykę Rolną UE (jako jeden z najbogatszych krajów świata Norwegia jest w stanie hojnie dotować swoich rolników, przeznaczając na dofinansowanie ok. 2,4 mld dolarów rocznie. Bez wsparcia ze strony państwa trudno byłoby zapewne konkurować na arenie międzynarodowej, przy jednoczesnym zmaganiu się $\mathrm{z}$ trudnym klimatem północnym) ${ }^{17}$.

Norweskie „NIE” dla członkostwa w Unii Europejskiej nie zamknęło współpracy z nią i jej państwami członkowskimi. „Europa stoi przed ogromnymi wyzwaniami. Stworzenie demokratycznej, stabilnej i bezpiecznej Europy wymaga ciężkiej pracy i zasobów i musi być oparte na konkretnych projektach współpracy. Musimy połączyć siły i wykorzystać tę okazję. Współpraca powinna się odbywać na szczeblu rządowym, regionalnym, europejskim i międzynarodowym. Norwegia jest zarówno chętna, jak i zainteresowana wzięciem części odpowiedzialności związanej z europejskimi wyzwaniami”, mówiła norweska sekretarz stanu Siri Bjerke w Instytucie Europejskim w Dublinie, w listopadzie 1995 r., podczas debaty poświęconej norweskiej perspektywie współpracy europejskiej ${ }^{18}$. Norweska debata publiczna na temat integracji europejskiej koncentrowała się wokół kwestii członkostwa, tego co jest dobre lub złe dla państwa, przedsiębiorstw lub osób

16 Nordic economies on road to recovery, http://www.norden.org/en/news-and-events/news/ nordic-economies-on-road-to-recovery (dostęp: 24 lipca 2015); Nordic Statistical Yearbook 2012; por. http://norden.statbank.dk/ (dostęp: 2 lipca 2015); OECD Economic Surveys: Norway 2014.

17 T. Hylland Eriksen, Being Norwegian in a shrinking World. Reflections on Norwegian identity, [w:] Continuity and Change: Aspects of Modern Norway, red. A.C. Kiel, Oslo 1993; por. J. Lindsell, The Norwegian Way. A case study for Britain's future relationship with the EU, Civitas: Institute for the Study of Civil Society, February 2015.

18 S. Bjerke, A Norwegian perspective on European co-operation, Institute of European Affairs, Dublin, 3.11.1995. 
fizycznych. Nie skupiano się na postawach norweskiego społeczeństwa wobec samego procesu integracji. Ten bowiem nie jest przez Norwegów negowany. Widać to na przykładzie relacji krajów w regionie nordyckim. Integracja nordycka poczyniła wiele przełomowych kroków i szybko osiągnęła poziom, do którego zmierzała bez sukcesu od początku swego istnienia Unia Europejska. Choć były również nieudane próby łączenia sił w skandynawskim obszarze. Od 1948 r. Nordycki Komitet Współpracy Ekonomicznej pracował nad projektem utworzenia wspólnego rynku - NORDEK. Próba ta zakończyła się fiaskiem ${ }^{19}$. Koncepcja upadła m.in. ze względu na związki Finlandii z ZSRR i przystąpienie Danii, Norwegii i Szwecji do Europejskiego Stowarzyszenia Wolnego Handlu (EFTA). Pomimo tego ustanowiono Radę Nordycką jako organ współpracy parlamentarnej (została powołana w 1952 r.), nordycką unię paszportową (w 1954 r.) i Nordycką Radę Ministrów (1971) jako instytucję współpracy międzyrządowej.

\section{Formy i płaszczyzny kontaktów Norwegii i UE}

Norwegia jest zaangażowana w działania na rzecz współpracy międzynarodowej i jest uczestnikiem wielu podmiotów, których celem jest zbliżenie krajów członkowskich na różnych płaszczyznach. Kraj ten jest od 1960 r. członkiem Europejskiego Stowarzyszenia Wolnego Handlu (EFTA), ponadto jest częścią Europejskiego Obszaru Gospodarczego, a także Układu z Schengen (Norwegia przystąpiła do niego w 2001 r.). Umowa o EOG weszła w życie 1 stycznia 1994 r. i jest kamieniem węgielnym stosunków między Norwegią a Unią Europejską. Skupia ona 28 państw UE oraz 3 kraje EFTA: Norwegię, Islandię i Liechtenstein i opiera się na czterech podstawowych swobodach: pracy, kapitału, towarów oraz usług. Porozumienie EOG obejmuje współpracę w innych ważnych dziedzinach, takich jak: badania i rozwój, edukacja, polityka społeczna, ochrona środowiska, ochrona konsumentów, turystyka i kultura. Umożliwia również państwom EFTA/EOG udział w różnych programach unijnych. Porozumienie EOG nie obejmuje Wspólnej Polityki Rolnej (WPR) i Wspólnej Polityki Rybołówstwa (WPRyb), unii celnej (Norwegia może mieć własne taryfy zewnętrzne) i walutowej oraz wspólnej polityki handlowej. Porozumienie nie dotyczy polityk objętych dawnym filarem $2-$ wspólnej polityki zagranicznej i polityki bezpieczeństwa (w ramach wspólnej polityki bezpieczeństwa i obrony Norwegia zawarła odrębne umowy z UE na udział

${ }^{19}$ Od chwili powstania Rada Nordycka prowadziła wysiłki na rzecz utworzenia wspólnego rynku. Jednak z chwilą przystąpienia Danii, Norwegii i Szwecji do Europejskiego Stowarzyszenia Wolnego Handlu (EFTA), nastąpił spadek zainteresowania tym tematem. Szerzej: B. Kołecka, Rada Nordycka, Nordycka Rada Ministrów, [w:] Europejskie struktury współpracy, red. S. Parzymies, Warszawa 2000, s. 182, A. Grochulski, NORDEK - nowy etap integracji krajów skandynawskich, „Sprawy Międzynarodowe” 1970, nr 3; R. Ławniczak, NORDEK a problem skandynawskiej unii celnej, „Przegląd Zachodni” 1969, nr 5; T. Knothe, Rada Nordycka, Biuro Stosunków Międzynarodowych Kancelarii Sejmu. Biuletyn Informacyjny, z. 1, wyd. II, Warszawa 1991. 
tego kraju w operacjach cywilnych i wojskowych oraz w działaniach Europejskiej Agencji Obrony). Norwegia ma wieloletnią tradycję polityki zagranicznej na Starym Kontynencie także jako założyciel Sojuszu Północnoatlantyckiego (NATO), członek Rady Europy i OBWE oraz w dawnym filarze 3 - sprawiedliwości i spraw wewnętrznych (Norwegia współpracuje z UE w zakresie zwalczania przestępczości transgranicznej, nielegalnej imigracji i zarządzania strumieniem uchodźców; dzieje się to w ramach różnych umów, a najważniejszą z nich jest układ z Schengen), wprowadzonych Traktatem z Maastricht. Centralną zasadą porozumienia EOG jest jednorodność, co oznacza, że te same zasady i warunki konkurencji mają być zastosowane wobec wszystkich podmiotów gospodarczych w ramach EOG. Aby zachować jednolitość, porozumienie EOG jest stale aktualizowane ${ }^{20}$.

Porozumienie EOG gwarantuje, że Norwegia korzysta ze swobodnego przepływu osób, towarów, usług i kapitału. To daje norweskim przedsiębiorstwom dostęp do „wspólnego rynku”, składającego się z 31 krajów o populacji ok. 500 milionów, a przepisy europejskie zapewniają, że konkurują oni na takich samych warunkach, jak firmy z krajów UE. Porozumienie EOG uprawnia Norwegów do życia, pracy i nauki w innych krajach europejskich. Umowa ułatwia także współpracę $\mathrm{w}$ zakresie ochrony cywilnej i planowania kryzysowego. Stabilność, bezpieczeństwo, zamożność, system opieki powodują, iż Norwegia jest atrakcyjnym miejscem do osiedlania się mimo chłodnego klimatu i peryferyjnej lokalizacji. Prawie 200000 obywateli UE/EOG obecnie tam pracuje. Więcej niż $7 \%$ siły roboczej Norwegii to obywatele UE/EOG.

W 2014 r. import Norwegii ogółem wyniósł 560723 mln koron z czego 63,8\% pochodziło z krajów UE (357 605 mln koron). Eksport w tym czasie wyniósł 897 $810 \mathrm{mln}$ koron, $\mathrm{z}$ czego $81,6 \%$ trafiło do Unii (732 $470 \mathrm{mln}$ koron). Norwegia jest jednym z największych eksporterów ryb na świecie. Około $60 \%$ eksportu wszystkich owoców morza trafia do UE. Protokół dodatkowy do Porozumienia EOG reguluje handel rybami i owocami morza między Norwegią a UE, a w ramach odrębnych umów strony negocjują roczne kwoty połowów i wolne kontyngenty taryfowe dla sprzedaży określonych towarów rolnych, takich jak: sery, mięsa, owoce, warzywa i kwiaty. Norwegia i UE ściśle współpracują w zakresie zarządzania zasobami morskimi, w tym w odniesieniu do monitorowania i egzekwowania przepisów. Wspólnie podejmują działania na rzecz zwalczania problemu nielegalnych, nieudokumentowanych i nieuregulowanych połowów (NNN). Ponadto Norwegia ściśle współpracuje z UE w zakresie zarządzania zasobami i ochrony

${ }^{20}$ Poza ustaloną w Porozumieniu o EOG formalną strukturą kontaktów odbywają się różne dwustronne spotkania na wysokim szczeblu między członkami rządu i Komisji oraz w Parlamencie Europejskim. Parlament zaprasza przedstawicieli Norwegii w celu przedstawienia polityki tego kraju w wielu kwestiach, takich jak: polityka energetyczna, udział Norwegii w działaniach pokojowych na Bliskim Wschodzie, w Arktyce i na Dalekiej Północy. Norwegia jest jedynym krajem spoza UE z wyznaczonym oficerem łącznikowym do Parlamentu Europejskiego. 
środowiska morskiego oraz uczestniczy w programach UE i działa jako partner $\mathrm{w}$ rozwoju europejskiej polityki morskiej ${ }^{21}$.

Ważną kwestią, zarówno dla UE, jak i Norwegii jest energia i związane z nią zmiany klimatu. Norwegia ma w pełni zintegrowany wewnętrzny rynek energii w ramach Porozumienia EOG. Kraj ten jest trzecim największym eksporterem gazu na świecie i lokuje się wśród największych eksporterów ropy. Prawie cały norweski gaz jest sprzedawany na rynku europejskim. Norwegia jest drugim co do wielkości w UE dostawcą produktów energetycznych (po Rosji), w tym ropy naftowej i gazu. Jest również jednym $\mathrm{z}$ największych na świecie producentów energii wodnej. Norweski gaz ziemny może odegrać ważną rolę w Europie przy przejściu na gospodarkę niskoemisyjną (emisja $\mathrm{CO}_{2}$ może zostać ograniczona poprzez zastąpienie węgla gazem. Uzupełnieniem gazu może być natomiast energia słoneczna i energia $z$ wiatru). To ważny aspekt relacji z Unią Europejską, dla której walka z globalnym ociepleniem i redukcja emisji gazów cieplarnianych są najważniejszymi celami polityki klimatycznej. Tym samym UE jest ważnym partnerem Norwegii we wdrażaniu strategii łagodzenia zmian klimatycznych.

EOG, EFTA i Schengen to główne powody, dla których Norwegia buduje nie tylko ekonomiczne, ale i polityczne i społeczne relacje z Unią Europejską. Te umowy kształtują politykę krajową na większości poziomów i w większości dziedzin. Dlatego Norwegia bierze aktywny udział w układaniu strategii działań na poziomie europejskim. Vidar Helgesen, norweski minister ds. europejskich w rządzie premier Erny Solberg, zilustrował to słowami: „To jest w naszym interesie narodowym, by ściślej współpracować z Unią Europejską oraz aktywnie uczestniczyć w trwających procesach politycznych w Europie. W celu skutecznego wpływania na ważne decyzje, Norwegia musi być bardziej przejrzysta i stanowcza i bardziej aktywna w debacie na temat polityki europejskiej”. I dalej: „Dla nas to jest ważniejsze niż dla jakiegokolwiek państwa członkowskiego być aktywnym na początku, przed złożeniem wniosków i podjęciem decyzji. Więc bierzemy udział w pracach Komisji, gdzie norwescy eksperci zabierają głos. Wiele z tych dyskusji ma charakter techniczny. Jeśli dyskutowane są kwestie polityczne, nasze braki wiedzy są bardziej widoczne, ponieważ nie jesteśmy obecni, gdy podejmowane są decyzje”22. Premier Solberg stwierdziła zaś: „nie ma dla nas miejsca podczas spotkań Unii, gdzie podejmowane są decyzje. Tak więc dostęp do jednolitego rynku UE jest kosztowny i wiąże się z »deficytem demokracji« dla Norwegii”"23. Przywódca norweskiej Socjalistycznej Partii Lewicy, Audun Lysbakken, również odwołuje się do deficytu demokracji w UE i do niedoskonałości konstrukcji Porozumienia EOG: „Nasza demokracja uczestnicząca jest osłabiana przez porozumienia EOG, sprowadzając Norwegię do roli biernego odbiorcy prawodawstwa UE. To zmierza

${ }^{21}$ Norway and the EU - partners for Europe, Norwegian Ministry of Foreign Affairs, 04.2015.

${ }^{22}$ Ibidem.

${ }^{23}$ Cyt. za: A. Leer, Norway's EU deal 'not right for UK', http://www.bbc.com/news/world-europe-22188028 (dostęp: 12 lipca 2015). 
do powszechnej regulacji szczegółów i szkodzi norweskiej polityce regionalnej i polityce gospodarczej. Umowa ma znacznie więcej wad niż zalet" ${ }^{24}$. Prof. Erik O. Eriksen, badacz norweskiego porozumienia z UE z Uniwersytetu z Oslo, twierdzi zaś, że brak możliwości wpływania obywateli kraju na treść praw powoduje, iż „zostaje uszkodzony demokratyczny łańcuch zarządzania”. Umowa o EOG przyniosła bowiem zmiany w postaci wprowadzenia ponad 10000 aktów prawnych UE w prawie norweskim ${ }^{25}$.

Przebieg tej politycznej dyskusji i przywoływane argumenty, a także wyniki badań prof. Eriksena, opublikowane w 2015 r., pozwalają skonstatować, iż Norwegia nie ma zamiaru stać się członkiem UE. Mimo to jest ona silnie zaangażowana we wspieranie procesu integracji europejskiej. Bycie częścią EOG kosztuje ten kraj prawie tyle, ile bycie pełnoprawnym członkiem Unii. Wkład Norwegii w społeczno-gospodarczy rozwój krajów UE jest ważnym następstwem Porozumienia o EOG. Kwota corocznej składki jest obliczana na podstawie względnej wielkości jego PKB w porównaniu do PKB EOG jako całości. W okresie programowania 2009-2014 Norwegia przeznaczyła 15 mld koron (1,8 mld euro, a największym ich beneficjentem była Polska, która otrzymała $578.1 \mathrm{mln}$ euro) dla krajów członkowskich Unii Europejskiej na minimalizowanie różnic społecznych i ekonomicznych (w latach 2004-2009 było to 1,3 mld euro). W 2014 r. kraj ten przekazał $306 \mathrm{mln}$ euro do budżetu UE, co stanowi 97\% wszystkich składek EFTA/EOG. Pomoc ta jest przekazywana za pośrednictwem 150 programów. W okresie 2014-2020 zaangażowanie Norwegii znacznie wzrośnie. 20 lipca 2015 r. Unia Europejska i Norwegia wspólnie zdecydowały o wysokości kolejnego wkładu Norwegii w spójność społeczną i gospodarczą Europy. Ustalono, iż będzie to ok. 3,3 mld koron rocznie (tj. 388 mln euro i ten wkład ma rosnąć do 550 mln euro w 2020 r.). Umowa obejmuje okres od 2014 do 2021 r. Podniesienie tej kwoty wynika z wyrównania o poziom inflacji poprzedniej kwoty dotacji, ustalonej w umowie z $2009 \mathrm{r}^{26}$

„Norwegia współpracuje z UE i z państwami członkowskimi dlatego, że dzielimy te same wartości i dlatego potrzebujemy wspólnych rozwiązań dla wspólnych wyzwań" - zapisano w programie współpracy na 2015 r. Wśród priorytetów znalazły się: konkurencyjność i wzrost, badania i edukacja, klimat i energia, sprawiedliwość i migracje, bezpieczeństwo i sprawy zagraniczne ${ }^{27}$. Minister ds. europejskich Helgesen podkreślił, iż Norwegii zależy na „stymulowaniu innowacyjności i wzrostu gospodarczego poprzez modernizację, rozwój badań i edukacji, a także

${ }^{24}$ Ibidem.

25 E.O. Eriksen, Despoiling Norwegian Democracy, [w:] E.O. Eriksen, J.E. Fossum, The European Union's Non Members. Independence under hegemony?, New York 2015, s. 77 n.

${ }^{26}$ Warto dodać, iż umowa ta była negocjowana równolegle do porozumienia o lepszym rynkowym dostępie do norweskich owoców morza, którego efektem są nowe, wyższe kontyngenty bezcłowe, co ma ogromne znaczenie dla norweskiego przemysłu owoców morza.

${ }^{27}$ Norway in Europe. The government's work programme for cooperation with the EU 2015, April 2015; por. Norway in Europe. The Norwegian Government's Strategy for Cooperation with the EU 2014-2017. 
zwiększanie mobilności na europejskim rynku pracy, by skutecznie walczyć ze zbyt wysokim bezrobociem wśród europejskiej młodzieży". Ponadto stwierdził: „Będziemy również kłaść nacisk na wzmocnienie europejskiego bezpieczeństwa energetycznego i przyczyniać się do ofensywnej polityki klimatycznej”28.

Od grudnia 2015 r. ministrem do spraw EOG i UE jest Elisabeth Aspaker. W lutym 2016 r. przedstawiła ona nowy program współpracy z Unią Europejską, który opiera się na działaniach z poprzednich lat, ale ze względu na przepływ uchodźców w Europie skupia się na sprawiedliwości i sprawach wewnętrznych ${ }^{29}$.

Zmiany klimatu, energia i innowacje jako priorytetowe dziedziny otrzymują najwięcej funduszy (około $40 \%$ wszystkich środków). Celem jest stworzenie lepszych warunków dla inteligentnego i zrównoważonego rozwoju oraz wzrostu gospodarczego zapobiegającego wykluczeniu społecznemu w Europie. Badania naukowe i edukacja także są ważnymi płaszczyznami kontaktów z UE. Poprzez Porozumienie EOG Norwegia uczestniczy w programie edukacyjnym Erasmus+ oraz Programie ramowym UE w zakresie badań naukowych i innowacji (Horyzont 2020). Wkład Norwegii w główne unijne programy promujące badania, innowacje i edukację wyniesie w latach 2014-2020 około 2,7 mld euro.

Norwegia wspiera również budowanie demokracji, ochronę praw człowieka i promocję integracji społecznej. Szczególną uwagę kraj ten zwraca na wzmocnienie społeczeństwa obywatelskiego i modernizację zdolności organizacji pozarządowych. Promuje ponadto dialog trójstronny i współpracę między pracownikami, pracodawcami i rządem. Norwegia wspiera także poprawę zdrowia, bezpieczeństwa i normy środowiskowe. Ponadto Norwegia jest głównym długoterminowym inwestorem w Unii Europejskiej. W styczniu 2014 r. „Government Pension Fund Global" zainwestował łącznie 235 mld euro w akcje i obligacje w krajach UE (co stanowi ok. $40 \%$ globalnych akcji i obligacji tego funduszu ${ }^{30}$.

\section{Zakończenie}

Powyższe rozważania skłaniają do zadania pytania, na które nie ma jednoznacznej odpowiedzi: to sukces czy porażka europejskiej wspólnoty państw? Norwegia jest częścią Europy, nie tylko geograficznie, ale również pod względem historycznym, finansowym i kulturowym. Unia Europejska jest najważniejszym partnerem handlowym tego państwa, a polityka UE ma wpływ na wiele sektorów życia norweskiego. Dlatego Norwegia aktywnie włącza się w konstrukcję Euro-

${ }^{28}$ Cyt. za: Norwegia i UE zgodne co do funduszy norweskich i bezcłowych kontyngentów, Ambasada Norwegii w Polsce, http://www.amb-norwegia.pl/news_and_events/pomoc-z-EOG/EOSAktuelt/Norwegia-i-UE-zgodne-co-do-funduszy-EOG-i-bezcowych-kontyngentow/\#.VcZuxXHtmko (dostęp: 8 sierpnia 2015).

${ }^{29}$ Norway in Europe. The Government's Work Programme For Cooperation With the EU, Norwegian Ministry of Foreign Affairs 2016.

${ }^{30}$ Norway and the EU - partners for Europe, op. cit. 
py, w której solidarność i bezpieczeństwo mają kluczowe znaczenie. Kraj ten jest w uprzywilejowanej sytuacji, w której mógł kształtować stosunki z UE. Jest częścią strefy wolnego handlu i swobodnego przemieszczania, bez konieczności przynależności do WPR, WPRyb i unii celnej. Europejscy włodarze bez zastanowienia przyjęliby Norwegię do swego grona, ponieważ ta stałaby się motorem dla unijnej koniunktury. Kraj jest stabilny politycznie, a jego gospodarka kwitnie. Norwegowie strzegą swego wysokiego PKB. Według danych Międzynarodowego Funduszu Walutowego w 2014 r. PKB per capita wynosił nominalnie 97013 335,2 mld dolarów, a po zmierzeniu parytetem siły nabywczej 66937 mld dolarów amerykańskich (2. miejsce w Europie po Luksemburgu i 6. miejsce na świecie) ${ }^{31}$.

Można zadać inne pytanie: czy Norwegia w ogóle potrzebuje UE? Unia Europejska jest skutecznym narzędziem naprawy relacji społeczno-ekonomicznych w państwach, które dzięki temu mają zagwarantowany status beneficjenta. Otwarcie rynku w Norwegii oznaczałoby wzrost konkurencyjności, a z nią — aktywizację małych i średnich przedsiębiorstw. Dla samych Norwegów zaś byłby to spadek cen towarów oraz żywności. Z politycznego punktu widzenia członkostwo dałoby norweskim władzom siłę współtworzenia UE. Norwegowie tę perspektywę jednak odrzucają. Warto zwrócić uwagę na fakt, iż dwukrotne „NIE” w referendach nie jest jedynie lękiem przed dominacją Brukseli i cesją suwerenności, ale czystą ekonomią. Norwegowie nie chcą dzielić się zyskiem z połowu ryb, a tym bardziej surowcami naturalnymi. Ich gospodarka jest zdrowa i dobrze prosperuje, nie będąc częścią Unii Europejskiej. To kraj, który w Europie jest najsłabiej dotknięty przez światowy kryzys gospodarczy. Norweska nieobecność w UE jest więc niczym innym, jak instynktem samozachowawczym, a eurosceptycyzm Norwegów jest oparty na przywiązaniu do autonomii. Ponadto sprzeciw wobec członkostwa w UE można tłumaczyć chęcią obrony norweskiego sposobu życia przed siłami centralizacji i europeizacji. Suma tych czynników powoduje, że debata na temat członkostwa kraju w Unii Europejskiej nie powraca. Ważne jednak jest to, iż nie ma konfliktu interesów między byciem Norwegiem, Skandynawem i Europejczykiem.

\section{Bibliografia}

Archer C., Norway and European Integration since 1994, „Queen's Papers on Europeanisation” 2001, nr 12.

Bagehot W., Nice up north. Why David Cameron is fascinated by Sweden and its neighbours, „The Economist", 27.01.2011.

Bjerke S., A Norwegian perspective on European co-operation, Institute of European Affairs, Dublin, 3.11.1995.

${ }^{31}$ World Economic and Financial Surveys. World Economic Outlook Database, International Monetary Fund April 2015. 
Consolidated Version Of The Treaty On European Union, „Official EN Journal of the European Union" C 326/13, 26.10.2012.

Document on The European Identity published by the Nine Foreign Ministers on 14 December 1973, in Copenhagen.

Eriksen E.O., Fossum J.E., The European Union's Non Members. Independence under hegemony?, New York 2015.

Eriksen T.H., Being Norwegian in a shrinking Word. Reflections on Norwegian identity, [w:] Continuity and Change: Aspects of Modern Norway, red. A.C. Kiel, Oslo 1993.

Grochulski A., NORDEK - nowy etap integracji krajów skandynawskich, „Sprawy Międzynarodowe" 1970, nr 3.

Knothe T., Rada Nordycka, Biuro Stosunków Międzynarodowych Kancelarii Sejmu. Biuletyn Informacyjny, z. 1, wyd. II, Warszawa 1991.

Kołecka B., Rada Nordycka, Nordycka Rada Ministrów, [w:] Europejskie struktury współpracy, red. S. Parzymies, Warszawa 2000.

Leer A., Norway's EU deal 'not right for UK', http://www.bbc.com/news/world-europe-22188028.

Lindsell J., The Norwegian Way. A case study for Britain's future relationship with the EU, Civitas: Institute for the Study of Civil Society, February 2015.

Ławniczak R., NORDEK a problem skandynawskiej unii celnej, „Przegląd Zachodni” 1969, nr 5.

Nordic economies on road to recovery http://www.norden.org/en/news-and-events/news/nordic-economies-on-road-to-recovery.

Nordic Statistical Yearbook 2012.

Norway and the EU - partners for Europe, Norwegian Ministry of Foreign Affairs, 04.2015.

Norway in Europe. The government's work programme for cooperation with the EU 2015, 04.2015.

Norway in Europe. The Norwegian Government's Strategy for Cooperation with the EU 2014-2017.

Norwegia $i$ UE zgodne co do funduszy norweskich i bezcłowych kontyngentów, Ambasada Norwegii w Polsce, http://www.amb-norwegia.pl/news_and_events/pomoc-z-EOG/EOSAktuelt/ Norwegia-i-UE-zgodne-co-do-funduszy-EOG-i-bezcowych-kontyngentow/\#.VcZuxXHtmko.

OECD Economic Surveys: Norway 2014.

Skinner M.S., Norwegian Euroscepticism: Values, Identity or Egotism? A Multi-level Mixed Methods Investigation, Bath 2011.

Spiering M., What is British Euroscepticism, [w:], Euroscepticism: Party Politics, National Identity and European Integration, red. Robert Harmsen, Menno Spiering, „European Studies” 2004, nr 20.

Taggart P., A Touchstone of Dissent: Euroscepticism in Contemporary West European Party Systems, „European Journal of Political Research” 1998, nr 33 (3).

Taggart P., Szczerbiak A., Opposing Europe: Party Systems and Opposition to the Union, the Euro and Europeanisation, „OERN Working Paper” 2000, nr 1. Brighton: University of Sussex, Sussex European Institute.

Taggart P., Szczerbiak A., Parties, Positions and Europe: Euroscepticism in the EU Candidate States of Central and Eastern Europe, „OERN Working Paper” 2001, nr 2. Brighton: University of Sussex, Sussex European Institute.

Taggart P., Szczerbiak A., The Party Politics of Euroscepticism in EU Member and Candidate States, "OERN Working Paper” 2002, nr 6. Brighton: University of Sussex, Sussex European Institute.

Taggart P., Szczerbiak A., Theorising Party-Based Euroscepticism: Problems of Definition, Measurement and Causality, „EPERN Working Paper” 2003, nr 12. Brighton: University of Sussex, Sussex European Institute.

The rationale for opposing Norwegian membership in the European Union, http://www.neitileu.no/ articles_in_foreign_languages/the_rationale_for_opposing_norwegian_membership_in_ the_european_union.

The reluctant European. Special Report, „, The Economist”, 17.10.2015. 
Meandry norweskiej europejskości

Woliński J., Referendum w Norwegii - komentarze ekspertów, http://www.psz.pl/168-archiwum/ referendum-w-norwegii-komentarze-ekspertow.

World Economic and Financial Surveys. World Economic Outlook Database. International Monetary Fund April 2015.

http://www.oxforddictionaries.com/definition/english/Eurosceptic.

http://news.bbc.co.uk/onthisday/hi/dates/stories/november/28/newsid_4208000/4208314.stm.

http://norden.statbank.dk/. 